International Journal of Life Sciences
Available online at www.sciencescholar.us
Vol. 5 No. 3, December 2021, pages: $179-190$
e-ISSN: 2550-6986, p-ISSN: 2550-6994
https://doi.org/10.53730/ijls.v5n3.2209

\title{
Performance and Blood Lipide Profile of Cockerel Aged 0-7 Weeks That Were Given Sambiloto Leaf Water Extract (Andrographis Paniculata Ness) Through Drinking Water
}

Gusti Putu Gunawijaya a , I Made Nuriyasa ${ }^{\text {b }}$, Ni Wayan Siti c

Manuscript submitted: 18 September 2021, Manuscript revised: 09 October 2021, Accepted for publication: 27 November 2021

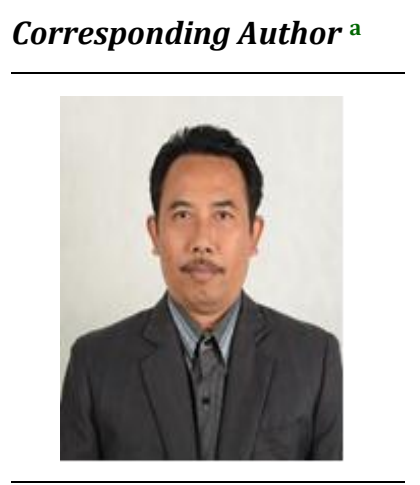

Keywords

aqueous extract; blood lipid profile; cockerel; leaf water; sambiloto;

\begin{abstract}
This study aims to examine the effect of adding water extract of Sambiloto (Andrographis paniculata Ness) to drinking water on the performance and blood lipids profilem of cockerel aged 0-7 weeks. This study was conducted in the village of Cepaka, Kediri, Tabanan, Bali. Using A total of 200 birds of aged 1 day old chick laying hens males. The experimental design used was a Completely Randomized Design (CRD) with four treatments and five replications so that there were 20 units, each replicate using 10 chickens. The treatments were: (A) Drinking water without the addition of extract sambiloto leaf water, (B) drinking water with the addition of sambiloto leaf water extract $2 \mathrm{ml} / \mathrm{l}$, (C) drinking water with the addition of sambiloto leaf water extract 4 $\mathrm{ml} / \mathrm{l}$ and (D) drinking water with the addition of sambiloto leaf water extract 6 $\mathrm{ml} / \mathrm{L}$ The variables observed in this study were performance, carcass, blood lipid profile, digestive tract microbes and economic aspec. The results showed that the administration of sambiloto leaf water extract not significantly different $(\mathrm{P}>0.05)$ on ration consumption, drinking water consumption, final body weight, FCR, blood lipid profile, total coliform and E.coly and significantly different $(\mathrm{P}<0.05)$ on carcass percentage, carcass composition.
\end{abstract}

International Journal of Life Sciences (C) 2021.

This is an open access article under the CC BY-NC-ND license (https://creativecommons.org/licenses/by-nc-nd/4.0/).

a Faculty of Animal Husbandry, Udayana University, Bali, Indonesia

b Faculty of Animal Husbandry, Udayana University, Bali, Indonesia

c Faculty of Animal Husbandry, Udayana University, Bali, Indonesia 


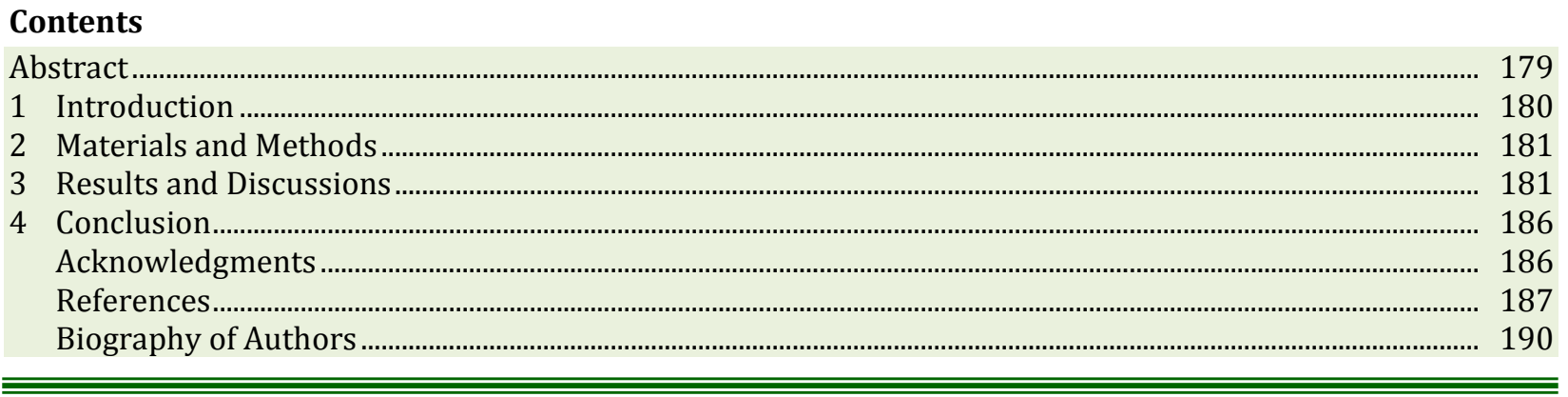

\section{Introduction}

The majority of male laying hens will be reared as broilers and only a small part will be used as animal feed, after being separated from the female DOC during hatching, healthy chickens will be selected for production purposes. Male Laying hens are sold at a very cheap price (0.02-0.03 US\$/laying hens compared to female laying hens 0.68-0.77 US\$/laying hens) to breeders and partnership companies (Soisontes, 2016). Laying hens are raised as in broiler rearing, but their need for protein and energy is lower because their growth rate is also lower (Salami et al., 2003). The use of Antibiotics Growth Promoter (AGP) in animal feed has long been used as a growth promoter with the aim of improving livestock performance and obtaining economic benefits. AGP means Growth-Stimulating Antibiotics or AGP is defined as all drugs that destroy and/or inhibit the growth of bacteria given in low doses or called Sub-Therapeutic doses which are added as additives in animal feed (FAO, 2001). The use of antibiotics is also able to increase the efficiency of the ration, so that it can benefit farmers (Mustaqim, 2006).

Antibiotics are widely used as AGP in animal feed around the world to stimulate livestock growth so that they can grow larger and faster and to prevent infection (Mitchell et al., 1998; Van den Bogaard et al., 2000; Radetsky, 1998). Several foodborne bacteria such as Salmonella, Campylobacter, Enterococci, and Escherichia coli that are resistant to antibiotics have been shown to be able to transfer resistant genes to humans through the food chain or by direct contact (Van den Bogaard et al., 2000). Based on the Ministry of Agriculture No. 14 concerning the prohibition of the use of AGP, the government regulation Law no. 18 of 2009 in conjunction with Law no. 41 of 2014 concerning Livestock and Animal Health Article 22 paragraph (4) letter c: "That everyone is prohibited from using feed that is mixed with certain hormones and or antibiotics as feed additives". (Kementan No 14/ 2017).since January 1, 2018 AGP in animal feed has been banned because it has a very negative impact on human health who consumes the livestock products, one of which is that it can cause resistance to various types of bacteria. Administration of antibiotics (AGP) in excessive and continuous amounts of feed will cause residues in livestock products. With the implementation of the AGP prohibition law, all animal feed factories have produced feed without AGP and it is a problem for farmers who have to find a solution to find a substitute for AGP, Prohibiting the use of AGP in animal feed has resulted in increased disease infections in chickens Knarreborg et al. (2002), Withdrawal of AGP in animal feed causes problematic livestock performance such as increased FCR, increased (subclinical) livestock diseases such as necrotic entrytis (Dibner \& Richards, 2005).

The search for alternative substitutes for Antibiotic growth promoter (AGP) in broiler feed continues to be carried out in line with the prohibition of the use of AGP in feed, several research results indicate that phytogenic feed additives from various types of plants have the potential to be used as an alternative to AGP in broiler feed (Hidayat \& Rahman, 2019). Chicken farmers are looking for AGP substitutes with various alternatives from several plant sources. Giving a mixture of sambiloto in poultry feed can prevent disease and improve the performance of chickens so that sambiloto can be used as a substitute for antibiotics (Srihanam, 2008). Tipakorn (2002), also found a decrease in mortality after adding $0.3 \%$ of bitter leaf powder (42.85 vs. $19.04 \%)$. The decrease in mortality in the addition of bitter leaf extract ( 0.1 and $0.2 \%)$ is supported by several studies which state that bitter has the ability to reduce swelling, inflammation, increase antibody production (immuno stimulant) (Puri, et al., 1993; Lü, 1995). the addition of $0.3 \%$ bitter leaf extract can replace the use of tetracycline in broiler rearing (Ulfah \& Natsir, 2018). The addition of sambiloto extract in drinking water is expected to increase the productivity of cockerel 1 by assisting in the process of absorption of feed which can 
replace the role of AGP in cockerel chicken farms in producing healthier meat products that are free from antibiotic residues.

\section{Materials and Methods}

\section{Chicken}

The research design used was Completely Randomized Design (CRD) with two hundred (200) day old cockerels divide to 4 treatments and 5 replications, each unit filled with 10 day old cockerels. Reared from 1 day to 7 weeks of age.

Cage research

The cage in this study used a battery colony cage made of wire as many as 20 plots of which each cage plot was 60 wide, 70 long and 35 high, with a floor base made of perforated wire..

\section{Rations and drinking water}

Rations and drinking water will be provided on an adlibitum basis, the ration used in this study is a commercial ration produced by PT. Cargill Indonesia. Which is in accordance with SNI standards (Indonesian national standards) standard starter rations (Broiler starter) in the form of crushed grains (crumbles) with $20 \%$ protein content and $0.50 \%$ aflatoxin from 0 to 7 weeks of age. The drinking water provided is water with a mixture of sambiloto leaf water extract at the level of (A) $0 \mathrm{ml} / \mathrm{l}$, (B) $2 \mathrm{ml} / \mathrm{l}$, (C) $4 \mathrm{ml} / \mathrm{l}$ and ((D) $6 \mathrm{ml} / \mathrm{l}$.

\section{Research variable}

Initial weight: initial weight is measured before the chicken is put in the treatment cage. Final body weight: Final body weight is calculated after the chicken is harvested, Weight gain is measured by the final weight minus the initial weight, and Ration consumption will be measured once a week the given ration is reduced by the remaining ration. Drinking water consumption: drinking water consumption will be measured every day using a measuring cup. Feed Convention Ratio (FCR): is a comparison between the amount of ration consumption and weight gain in the same period. Percentage of carcass parts consisting of carcass weight, carcass percentage, meat percentage, fat percentage, bone weight.

a. Blood lipid profile : The blood lipid profile measured was total cholesterol, triglycerides, LDL and HDL

b. Bacteria in broiler cecum, measured was Total E.Coly and Colliform

c. Economic aspec: Total revenue, Total cost, Profit, RC/Ratio, BEP.

\section{Data analysis}

The data obtained will be analyzed by means of variance. If there were significantly different results between treatments $(\mathrm{P}<0.05)$, the analysis was continued with Duncan's multiple distance test (Mathivanan et al., 2006; World Health Organization, 1997). The economic aspect will be carried out with descriptive analysis.

\section{Results and Discussions}

The initial and final weights of cockerel are presented in table 1 . The results showed no significantly different results $(\mathrm{P}>0.05)$. This was due to the uniformity of DOC and feed management, maintenance, in accordance with the opinion of Lacy \& Vest (2000), stating some of the main factors that affect the conversion of rations

Gunawijaya, G. P., Nuriyasa, I. M., \& Siti, N. W. (2021). Performance and blood lipide profile of cockerel aged 0-7 weeks that were given sambiloto leaf water extract (Andrographis paniculata ness) through drinking water. International Journal of Life Sciences, 5(3), 179-190. https://doi.org/10.53730/ijls.v5n3.2209 
are genetics, ration quality, disease, temperature, cage sanitation, ventilation, treatment, and cage management, ration factors, lighting also plays a role in influencing ration conversion, the rate of travel of the ration in the digestive tract, the physical form of the ration and nutritional composition of the ration.

Consumption of rations and consumption of drinking water in all treatments showed no significant results $(P>0.05)$. This was because the feed rations for the four treatments were the same so that the nutritional needs of the chickens were met with the rations given. This is in line with the opinion of Suwarta et al. (2021), Supplementation of a mixture of turmeric and bitter flour to a level of $40 \mathrm{~g} / \mathrm{kg}$ in the ration could not improve the performance of laying hens, but supplementation at a level of $10 \mathrm{~g} / \mathrm{kg}$ in the ration would improve egg production (HDA) and feed conversion of laying hens, moderate other production variables are relatively the same. Bidura et al. (2017), that the administration of herbal extracts (leaves and garlic) drinking water as much as $5 \mathrm{cc} / 100 \mathrm{cc}$ did not significantly affect the consumption of rations and drinking water (Ceccato et al., 2001; Maki et al., 2004).

The value of Feed Conversion Ratio (FCR) did not show a significant difference $(P>0.05)$ because the treatment had no significant effect on ration consumption and weight gain so that the ration conversion did not show any difference. Provision of rations with the same nutritional level and environmental conditions with the same temperature. Mathivanan et al. (2006), stated that the use of sambiloto in feed as a natural antibiotic had no effect on broiler feed consumption.

Table 1

Effect of leaf water extract of sambiloto (Andrographis Paniculata Ness) through drinking water on Cockerel performance

\begin{tabular}{lcccrr}
\hline \multirow{2}{*}{ Variabel } & \multicolumn{4}{c}{ Perlakuan $^{1)}$} & SEM $^{2}$ \\
\cline { 2 - 5 } & $\mathrm{A}$ & $\mathrm{B}$ & $\mathrm{C}$ & $\mathrm{D}$ & \\
\hline Initial Body Weight (g) & $42.20 \mathrm{a}$ & $42.40 \mathrm{a}$ & $42.20 \mathrm{a}$ & $41.60 \mathrm{a}$ & 0.35 \\
Final body weight (g) & $849.80 \mathrm{a}$ & $861.00 \mathrm{a}$ & $828.40 \mathrm{a}$ & $828.00 \mathrm{a}$ & 13.2 \\
Weight gain (g) & $807.80 \mathrm{a}$ & $818.80 \mathrm{a}$ & $786.20 \mathrm{a}$ & $786.60 \mathrm{a}$ & 13.15 \\
Feed consumption (g) & $1666.88 \mathrm{a}$ & $1650.00 \mathrm{a}$ & $1629.80 \mathrm{a}$ & $1620.48 \mathrm{a}$ & 54.2 \\
Ration Conversion & $2.00 \mathrm{a}$ & $1.96 \mathrm{a}$ & $2.01 \mathrm{a}$ & $2.04 \mathrm{a}$ & 0.07 \\
Drinking Water Consumption & $5237.8 \mathrm{a}$ & $5237.8 \mathrm{a}$ & $5158.8 \mathrm{a}$ & $5079.8 \mathrm{a}$ & 146 \\
(ml) & & & &
\end{tabular}

Description:

A: Provision of drinking water without the addition of sambiloto water extract as a control.

B: provision of drinking water with the addition of $2 \mathrm{ml} /$ liter of sambiloto water extract.

C: giving drinking water with the addition of $4 \mathrm{ml} /$ liter of sambiloto water extract.

D: and giving drinking water with the addition of $6 \mathrm{ml} /$ liter of sambiloto water extract

\section{Percentage of carcass}

The results in table 2 show that the percentage of carcasses in treatment D showed significantly different results $(\mathrm{P}<0.05)$ with treatments A.B. and C. This is presumably due to the effect of compounds contained in bitter leaf as antioxidants, antiseptics, natural antibiotics, so that the absorption of nutrients will be maximized causing maximum ration efficiency so that it will affect the carcass percentage, meat percentage, and fat percentage and bone percentage. According to Mustaqim (2006), giving sambiloto flour at a dose of $0.4-0.8 \%$ gave a significant effect in reducing the proportion of pancreatic weight. Soeparno (2005), stated that factors, age, and growth rate could affect the carcass component. 
Tabel 2

Average Percentage of male laying hens carcasses that received the addition of sambiloto (Andrographis Paniculata Ness) leaf water extract until 7 weeks of age.

\begin{tabular}{lrlrrr}
\hline \multicolumn{1}{c}{ Variabel } & \multicolumn{3}{c}{ Treatment } & \multicolumn{2}{c}{ SEM $^{2)}$} \\
\cline { 2 - 6 } & $\mathrm{A}$ & $\mathrm{B}$ & $\mathrm{C}$ & $\mathrm{D}$ & \\
Carcass Percentage & $56.00 \mathrm{~b}$ & $56.60 \mathrm{~b}$ & $55.40 \mathrm{~b}$ & $53.20 \mathrm{a}$ & 0.71 \\
Carcass fat percentage & $16.61 \mathrm{~b}$ & $13.48 \mathrm{a}$ & $12.83 \mathrm{a}$ & $12.30 \mathrm{a}$ & 55 \\
Meat percentage & $47.18 \mathrm{a}$ & $53.15 \mathrm{c}$ & $52.54 \mathrm{c}$ & $50.28 \mathrm{~b}$ & 0.69 \\
Bone percentage & $36.19 \mathrm{~b}$ & $32.73 \mathrm{a}$ & $34.62 \mathrm{ab}$ & $40.04 \mathrm{c}$ & 0.78 \\
\hline
\end{tabular}

Description:

A: Provision of drinking water without the addition of sambiloto water extract as a control.

B: provision of drinking water with the addition of $2 \mathrm{ml} /$ liter of sambiloto water extract.

C: giving drinking water with the addition of $4 \mathrm{ml} /$ liter of sambiloto water extract.

D: and giving drinking water with the addition of $6 \mathrm{ml} /$ liter of sambiloto water extract

Carcass Fat Percentage from the results of the study that the Fat Percentage in treatment A showed significantly different results $(\mathrm{P}<0.05)$ with treatments $\mathrm{BC}$ and $\mathrm{D}$. This was because Sambiloto contains flavonoid compounds, lactones and terpenoids (Warditiani et al., 2014 ; Imanta, 2017). In the Sambiloto plant, flavonoids have the highest content in the roots (Imanta, 2017). Flavonoids can inhibit Fatty Acid Synthase (FAS), which is an important enzyme in fat metabolism. The presence of inhibition on FAS directly reduces fatty acid formation (Tian et al., 2011). The results of this study showed that the percentage of meat in treatment A: 47.18 was significantly different $(P<0.05)$ with treatment $D$ : 50.28 but was very significantly different $(\mathrm{P}>0.05)$ with treatment B: 53.15 and C: 52.54 . Digest chicken while inhibiting the growth of pathogenic bacteria in the digestive tract (Jayanata \& Harioanto, 2011). This increase in the digestibility of chickens causes the absorbed feed to be more perfect and the digestive tract of the chickens to be healthier, the absorbed feed can be converted more efficiently into meat (Caveny et al., 1981; Lessire et al., 1982).

Bone Percentage the results of this study showed that the percentage of bone in treatment $\mathrm{D}$ was significantly different $(\mathrm{P}<0.05)$ with treatments $\mathrm{A}, \mathrm{B}$, and $\mathrm{C}$. This was due to the lower fat percentage than treatment A, B and C. While Sambiloto contains flavonoid compounds, lactones and terpenoids (Warditiani et al., 2014; Imanta, 2017). The flavonoids have the highest content in the roots (Imanta, 2017). Flavonoids can inhibit Fatty Acid Synthase (FAS), which is an important enzyme in fat metabolism. The presence of inhibition on FAS directly reduces fatty acid formation (Tian et al., 2011).

\section{Blood lipid profile}

Cholesterol In this study, total blood cholesterol was obtained for the treatment A:132 ,B:119. C 125, and D 122 was not significantly different $(\mathrm{P}>0.05)$ this was due to the aqueous extract of sambiloto used had not been able to reduce cholesterol in the blood of male hens. in accordance with the opinion of Nururianie (2005) that the results of the analysis of rat serum showed that the ethanol fraction of the infusion of Sambiloto herb at 1.31 and $2.62 \mathrm{~g} / \mathrm{Kg} \mathrm{BW}$ significantly $(\mathrm{p}<0.05)$ could reduce total cholesterol levels in mice. $53.23 \%$ and $72.88 \%$ respectively when compared to the control. The results obtained in this study that the triglyceride content was A: 88500, B: 115500 , C: 115000 and D: 99500 statistically not significantly different $(\mathrm{P}>0.05)$. Plasma lipids consist of triglycerides (free fat), phospholipids, cholesterol (cholesterol), cholesterol esters, and free fatty acids. Lactic acid bacteria have Bile Salt Hydrolase which plays a role in the deconjugation of bile acids which will produce free or deconjugated bile salts to form free cholic acid which is poorly absorbed by the intestines (González-Santiago et al., 2006; Carvalho et al., 2010).

In this study, obtained HDL treatment A: 93,000, B: 87000 C97500 and D: 92500 Bitter root extract can reduce LDL and triglyceride levels in the blood of white wistar rats. Dosage C $300 \mathrm{mg} / \mathrm{kgBW} /$ day has an effect equivalent to rosuvastatin $0.18 \mathrm{~g} / 200 \mathrm{mgBW} /$ day (Wibowo \& Sutrisna, 2020). The content of triglycerides decreased and HDL increased, this happened because of the process of releasing cholesterol esters into the

Gunawijaya, G. P., Nuriyasa, I. M., \& Siti, N. W. (2021). Performance and blood lipide profile of cockerel aged 0-7 weeks that were given sambiloto leaf water extract (Andrographis paniculata ness) through drinking water.

International Journal of Life Sciences, 5(3), 179-190. https://doi.org/10.53730/ijls.v5n3.2209 
liver carried out by hepatic lipase which hydrolyzes HDL and triglycerides to provide cholesterol for bile acid production and HDL concentrations vary reciprocally with triglyceride concentrations (Granner, 2003).

Table 3

Average Cholesterol, Triglycerides, HDL and LDL in the blood of Cokerel who received the addition of sambiloto(Andrographis Paniculata Ness) water extract until the age of 7 weeks

\begin{tabular}{lrrrrr}
\hline \multirow{2}{*}{ Variable } & \multicolumn{4}{c}{ Treatment } & \multirow{2}{*}{ SEM } \\
\cline { 2 - 5 } & \multicolumn{1}{c}{ A } & \multicolumn{1}{c}{ B } & C & D & \\
\hline Total blood cholesterol & & & & & \\
(mg/dl) & $132 \mathrm{a}$ & $119 \mathrm{a}$ & $125 \mathrm{a}$ & $122 \mathrm{a}$ & 5.96 \\
Blood triglycerides (mg/dl) & $88 \mathrm{a}$ & $115 \mathrm{a}$ & $115 \mathrm{a}$ & $99 \mathrm{a}$ & 14.36 \\
blood HDL (mg/dl) & $93 \mathrm{a}$ & $87 \mathrm{a}$ & $97 \mathrm{a}$ & $92 \mathrm{a}$ & 3.02 \\
blood LDL (mg/dl) & $32 \mathrm{a}$ & $28 \mathrm{a}$ & $27 \mathrm{a}$ & $27 \mathrm{a}$ & 4.35 \\
\hline
\end{tabular}

Description:

A: Provision of drinking water without the addition of sambiloto water extract as a control.

B: provision of drinking water with the addition of $2 \mathrm{ml} /$ liter of sambiloto water extract.

C: giving drinking water with the addition of $4 \mathrm{ml} /$ liter of sambiloto water extract.

D: and giving drinking water with the addition of $6 \mathrm{ml} /$ liter of sambiloto water extract

\section{Bacteria in the digestive tract}

The number of $\mathrm{E}$ coli and Coliform bacteria The results of the analysis of variance showed that the administration of sambiloto water extract at a level of $6 \mathrm{ml} / \mathrm{l}$ of drinking water had no significant effect $(\mathrm{P}>0.05)$ on the number of $\mathrm{E}$ coli and coliform bacteria in laying hens. Bitter extract treatment has not been able to reduce the growth of bacterial colonies. However, the sambiloto extract treatment has not been able to completely reduce the total number of $\mathrm{E}$ coli and Coliform in the digestive tract the growth of bacterial colonies in the sambiloto extract treatment was caused by the dose and content of the active compounds that had not been able to inhibit growth in the gastrointestinal tract of laying hens. According to Rachmawati \& Hamid (2014), which states that sambiloto is bacteriostatic against Pseudomonas aeruginos. Antibacterial effectiveness was influenced by the number of doses given and the amount of sambiloto consumed by the chickens. The higher the administration of bitter leaf flour, the difference in the number of bacteria growth will decrease (Rosa et al., 2019). The active substances contained in bitter leaves that can inhibit bacterial growth are flavonoids Cushnie \& Lamb (2005); Yulianti et al. (2015), that sambiloto flour supplementation at $0.4 \%$ level will reduce egg production.

Table 4

The average E Colli and Coliform on digestive track of cockerel that received the addition of sambiloto

(Andrographis Paniculata Ness) leaf water extract until the age of 7

\begin{tabular}{lccccl}
\hline \multicolumn{1}{c}{ Variable } & \multicolumn{3}{c}{ Treatment } & SEM \\
\hline & $\mathrm{A}$ & $\mathrm{B}$ & $\mathrm{C}$ & $\mathrm{D}$ & \\
E.Colly $(\mathrm{CFU} / \mathrm{g})$ & $6 \times 10^{6} \mathrm{a}$ & $495 \times 10^{6} \mathrm{a}$ & $27 \times 10^{6} \mathrm{a}$ & $180 \times 10^{6} \mathrm{a}$ & $81 \times 10^{6}$ \\
Collyform $(\mathrm{CFU} / \mathrm{g})$ & $295 \times 10^{6} \mathrm{a}$ & $821 \times 10^{6} \mathrm{a}$ & $540 \times 10^{6} \mathrm{a}$ & $800 \times 10^{6} \mathrm{a}$ & $469 \times 10^{6}$ \\
\hline
\end{tabular}

Description:

A: Provision of drinking water without the addition of sambiloto water extract as a control.

B: provision of drinking water with the addition of $2 \mathrm{ml} /$ liter of sambiloto water extract.

C: giving drinking water with the addition of $4 \mathrm{ml} /$ liter of sambiloto water extract.

D: and giving drinking water with the addition of $6 \mathrm{ml} /$ liter of sambiloto water extract 


\section{Economic aspect}

The results of this study indicate that the total acceptance of laying roosters for 1000 tails in treatment $\mathrm{A}$ is Rp. 33,960,000, Treatment B is Rp. 34,440,000, and Treatment C is Rp. 33,120,000. Treatment D is Rp. $33,080,000$. Business revenue can be obtained from the sale of chicken and fertilizer sales. This is because at a concentration of $2 \mathrm{ml} /$ liter is the most appropriate. The results of this study indicate that the administration of sambiloto water extract through drinking water has the highest productivity in treatment $\mathrm{B}(2 \mathrm{ml} / \mathrm{l}$.). Antiamoeba Mills \& Bone (2000), which can protect livestock from various infectious diseases, thus providing a beneficial impact for farmers. The largest percentage of production costs in this study is the cost of feed where in treatment A 71.91\%, treatment B 71.66\%, treatment C $71.41 \%$, and treatment D $71.41 \%$, in accordance with Pakarti (2000) who stated that the largest cost component in the chicken farming business meat is the cost of feed, which reaches $69 \%$ of the total cost of production (Singh \& Rajini, 2004; Sulaiman et al., 2008).

The results of the economic analysis of 1000 laying roosters on the business profits of laying roosters with the addition of sambiloto water extract caused an increase in growth and decreased feed consumption so as to increase profits. The growth of chickens given the extract of sambiloto water at a dose of $2 \mathrm{ml} / \mathrm{l}$ of drinking water (Treatment B) gave the best growth, with a profit of Rp. 15,560,000 Meanwhile for treatment A, C and D of 14,916,000. Rp.14,404,000 and 14,364,000 This increase in income was due to lower feed costs and increased sales of chickens due to increased chicken weight. Hoddi \& Rombe (2011), stated that the profit earned by broiler breeders is the result of the sale of livestock minus the costs incurred during the production period (Widyawaruyanti et al., 2014; Oka, 2021; Hidir et al., 2021).

The results of the analysis found that the largest RC/Ratio in treatment B was Rp. 1.17, which means that every Rp. 1,000,000 and one million rupiahs spent in the business generates Rp. 1,820,000, while for treatment A 1,780,000, treatment $\mathrm{c}$ is Rp. $1,770,000$ and treatment $\mathrm{D}$ is Rp. 1,770,000. The results of operations with $\mathrm{RC} /$ Ratio above 1 are said to be feasible. The results of this study indicate that giving sambiloto water extract to laying hens can increase the profits obtained by breeders or giving sambiloto water extract to increase the efficiency of chicken rearing. Ismail et al. (2014), stated that rearing broiler chickens with a close house system is efficient and feasible because it has an R/C ratio of more than 1 , while Suwiangadana et al. (2013), also states that broiler rearing business with a partnership pattern is feasible because it has an $\mathrm{R} / \mathrm{C}$ ratio of 1.07 and 1.08 .

Break Even Point (BEP)The BEP value of the selling price in the study, respectively, for Treatment A was Rp. 22,290, Treatment B was Rp. 21,789., Treatment C was Rp. 22,459, and treatment D was Rp. 22,486. Treatment B has the lowest BEP value. It means that if the selling price is Rp. 21,789. Then we have no profit and no loss because 21,789 tails is the break-even point for the selling price of chickens per kg. According to Prawira et al. (2017), the close house system broiler farming business in a partnership pattern with a capacity of 11,000 heads gets a unit BEP value of Rp. 15,783,-/ kg with a contract price of Rp. 16,517/kg-Rp.18,299/kg so that it will not cause farmers to make a loss. Giving sambiloto extract through drinking water can reduce livestock production costs, this is because it can save feed costs and increase livestock growth so as to increase sales results. Conversion Feed costs are closely related to production costs, because increasing feed conversion means that the production costs of each unit of body weight will increase (Yunilas \& Sinaga, 2005)

Table 5

Results of Economic Calculations for a 1000 Cockerel that received the Addition of Sambiloto (Andrographis Paniculata Ness) Leaf Water Extract until the Age of 7 Weeks

\begin{tabular}{lcccc}
\hline \multirow{2}{*}{ Variable } & \multicolumn{4}{c}{ Tratment } \\
\cline { 2 - 5 } & $\mathrm{A}$ & $\mathrm{B}$ & $\mathrm{C}$ & $\mathrm{D}$ \\
\hline Total revenue (Rp) & $33,960,000$ & $34,440,000$ & $33,120,000$ & $33,080,000$ \\
Total Cost(Rp) & $19,044,000$ & $18,880,000$ & $18,716,000$ & $18,716,000$ \\
Profit (Rp) & $14,916,000$ & $15,560,000$ & $14,404,000$ & $14,364,000$ \\
RC/Ratio (Rp) & 1.78 & 1.82 & 1.77 & 1.77 \\
BEP (Rp/Kg(Rp) & 22,290 & 21,789 & 22,459 & 22,486 \\
\hline
\end{tabular}

Gunawijaya, G. P., Nuriyasa, I. M., \& Siti, N. W. (2021). Performance and blood lipide profile of cockerel aged 0-7 weeks that were given sambiloto leaf water extract (Andrographis paniculata ness) through drinking water. International Journal of Life Sciences, 5(3), 179-190. https://doi.org/10.53730/ijls.v5n3.2209 
Description:

A: Provision of drinking water without the addition of sambiloto water extract as a control.

B: provision of drinking water with the addition of $2 \mathrm{ml} /$ liter of sambiloto water extract.

C: giving drinking water with the addition of $4 \mathrm{ml} /$ liter of sambiloto water extract.

D: and giving drinking water with the addition of $6 \mathrm{ml} /$ liter of sambiloto water extract

\section{Conclusion}

From the results of this study it can be concluded that:

1. Giving sambiloto water extract in drinking water for coockerel until the age of 7 weeks has no effect on performance.

2. Optimum level Giving sambiloto water extract $2 \mathrm{ml} / \mathrm{l}$ which can positive affect the carcass.

3. The administration of sambiloto water extract level $2-6 \mathrm{ml} / \mathrm{l}$ in drinking water of coockerel until the age of 7 weeks did not affect the blood lipid profile, coliform and E.coly.

4. Economically, the addition of sambiloto water extract at the level of $2 \mathrm{ml} / \mathrm{l}$ in drinking water resulted in optimal benefits.

From the results of this study, it can be suggested to provide water extract of sambiloto $2 \mathrm{ml} / \mathrm{l}$ in drinking water so that performance is better and gives more benefits to farmers.

Acknowledgments

We are grateful to two anonymous reviewers for their valuable comments on the earlier version of this paper. 


\section{References}

Bidura, I. G. N. G., Partama, I. B. G., Putri, B. R. T., \& Watiniasih, N. L. (2017). Effect of water extract of two leaves (Allium sativum and Sauropus androgynus) on egg production and yolk cholesterol levels in egg laying hens. Pakistan Journal of Nutrition, 16(7), 482-487.

Carvalho, J., Marques, E., Ascensão, A., Magalhães, J., Marques, F., \& Mota, J. (2010). Multicomponent exercise program improves blood lipid profile and antioxidant capacity in older women. Archives of gerontology and geriatrics, 51(1), 1-5. https://doi.org/10.1016/j.archger.2009.05.020

Caveny, D. D., Quarles, C. L., \& Greathouse, G. A. (1981). Atmospheric ammonia and broiler cockerel performance. Poultry Science, 60(3), 513-516. https://doi.org/10.3382/ps.0600513

Ceccato, P., Flasse, S., Tarantola, S., Jacquemoud, S., \& Grégoire, J. M. (2001). Detecting vegetation leaf water content using reflectance in the optical domain. Remote sensing of environment,77(1), 22-33. https://doi.org/10.1016/S0034-4257(01)00191-2

Cushnie, T. T., \& Lamb, A. J. (2005). Antimicrobial activity of flavonoids. International journal of antimicrobial agents, 26(5), 343-356.

Dibner, J. J., \& Richards, J. D. (2005). Antibiotic growth promoters in agriculture: history and mode of action. Poultry science, 84(4), 634-643.

FAO. (2001). The State of Food and Agriculture 2001 (No. 33). Food \& Agriculture Org..

González-Santiago, M., Martín-Bautista, E., Carrero, J. J., Fonolla, J., Baró, L., Bartolomé, M. V., ... \& LopezHuertas, E. (2006). One-month administration of hydroxytyrosol, a phenolic antioxidant present in olive oil, to hyperlipemic rabbits improves blood lipid profile, antioxidant status and reduces atherosclerosis development. Atherosclerosis, 188(1), 35-42. https://doi.org/10.1016/j.atherosclerosis.2005.10.022

Granner, D. K. (2003). Hormon Pankreas dan Traktus Gastrointestinal. Dalam: Murray, RK, Granner, DK, Mayes, PA, \& Rodwell, VW Biokimia Harper. Edisi, 25, 582-593.

Hidayat, C., \& Rahman, R. (2019). Peluang Pengembangan Imbuhan Pakan Fitogenik Sebagai Pengganti Antibiotika dalam Ransum Ayam Pedaging di Indonesia. Jurnal Ilmu dan Teknologi Peternakan Tropis, 6(2), 188-213.

Hidir, A., Zunaidi, A., \& Pattiasina, P. J. (2021). Understanding human resources management strategy in implementing good government practice: what research evidence say. International Research Journal of Management, IT and Social Sciences, 8(3), 265-273. https://doi.org/10.21744/irjmis.v8n3.1658

Hoddi, A. H., \& Rombe, M. B. (2011). Analisis Pendapatan Peternakan Sapi Potong di Kecamatan Tanete Rilau, Kabupaten Barru. Fakultas Peternakan UNHAS.

Imanta, E. (2017). Uji biolarvasida nyamuk aedes aegypty dari hasil isolasi ekstrak metanol tanaman sambiloto (Andrographis paniculata NESS). Unesa Journal of Chemistry, 6(1).

Ismail, I., Utami, H. D., \& Hartono, B. (2014). Analisa ekonomi usaha peternakan broiler yang menggunakan dua tipe kandang berbeda. Jurnal Ilmu-Ilmu Peternakan (Indonesian Journal of Animal Science), 23(3), 1116.

Jayanata, C. E., \& Harianto, B. (2011). 28 Hari Panen Ayam Broiler. AgroMedia.

Knarreborg, A., Simon, M. A., Engberg, R. M., Jensen, B. B., \& Tannock, G. W. (2002). Effects of dietary fat source and subtherapeutic levels of antibiotic on the bacterial community in the ileum of broiler chickens at various ages. Applied and environmental microbiology, 68(12), 5918-5924.

Lacy, M., \& Vest, L. R. (2000). Improving Feed in Broiler: A Guide for Growers.

Lessire, M., Leclercq, B., \& Conan, L. (1982). Metabolisable energy value of fats in chicks and adult cockerels. Animal Feed Science and Technology, 7(4), 365-374. https://doi.org/10.1016/03778401(82)90006-2

Lü, W. (1995). Prospect for study on treatment of AIDS with traditional Chinese medicine. Journal of traditional Chinese medicine= Chung i tsa chih ying wen pan, 15(1), 3-9.

Maki, M., Ishiahra, M., \& Tamura, M. (2004). Estimation of leaf water status to monitor the risk of forest fires by using remotely sensed data. Remote Sensing of Environment, 90(4), 441-450. https://doi.org/10.1016/j.rse.2004.02.002

Mathivanan, R., Edwin, S. C., Amutha, R., \& Viswanathan, K. (2006). Panchagavya and Andrographis paniculata as alternatives to antibiotic growth promoter on broiler production and carcass characteristics. International Journal of Poultry Science, 5(12), 1144-1150.

Gunawijaya, G. P., Nuriyasa, I. M., \& Siti, N. W. (2021). Performance and blood lipide profile of cockerel aged 0-7 weeks that were given sambiloto leaf water extract (Andrographis paniculata ness) through drinking water.

International Journal of Life Sciences, 5(3), 179-190. https://doi.org/10.53730/ijls.v5n3.2209 
Mathivanan, S., Periaswamy, B., Gandhi, T. K. B., Kandasamy, K., Suresh, S., Mohmood, R., ... \& Pandey, A. (2006). An evaluation of human protein-protein interaction data in the public domain. $B M C$ bioinformatics, 7(5), 1-14.

Mills, S., \& Bone, K. (2000). Principles and practice of phytotherapy. Modern herbal medicine. Churchill Livingstone.

Mitchell, J. M., Griffiths, M. W., McEwen, S. A., McNab, W. B., \& Yee, A. J. (1998). Antimicrobial drug residues in milk and meat: causes, concerns, prevalence, regulations, tests, and test performance. Journal of food protection, 61(6), 742-756.

Mustaqim. (2006). Persentase bobot karkas, organ dalam, dan lemak abdomen broiler yang diberi imbuhan tepung daun sambiloto (Andrographis paniculataNees). J.Ilmu Peternakan 9(16):112-118

Nururianie, D. (2005). Efek Fraksi Etanol Infusa Herba Sambiloto [Andrographis paniculata (Burm. f.) Nees] terhadap Kadar Kolesterol Total Tikus Jantan Wistar yang Diberi Diet Lemak Tinggi.

Oka, A. A. (2021). Utilizing digital applications in improving student learning outcomes (review of biology teaching and learning strategies). International Research Journal of Management, IT and Social Sciences, 8(5), 476-486. https://doi.org/10.21744/irjmis.v8n5.1924

Pakarti, S. I. B. (2000). Efisiensi Penggunaan Faktor-faktor Produksi dan Tingkat Pendapatan Peternak Ayam Broiler (Studi Kasus Pada Kelompok Peternak Plasma Poultry Shop Jaya Broiler di Kabupaten Kuningan, Jawa Barat). Skripsi. Fakultas Peternakan, Institut Pertanian Bogor, Bogor.

Prawira, A., Oosting, S. F., Chen, T. W., Delos Santos, K. A., Saluja, R., Wang, L., ... \& Hansen, A. R. (2017). Systemic therapies for recurrent or metastatic nasopharyngeal carcinoma: a systematic review. British journal of cancer, 117(12), 1743-1752.

Puri, A., Saxena, R., Saxena, R. P., Saxena, K. C., Srivastava, V., \& Tandon, J. S. (1993). Immunostimulant agents from Andrographis paniculata. Journal of Natural products, 56(7), 995-999.

Rachmawati, S., \& Hamid, H. (2014). Pengaruh Penggunaan Sambiloto (Andrographis paniculata Ness) terhadap Kandungan Residu Aflatoksin dalam Hati Itik dan Hubungannya dengan Atlatoksikosis. JITV, 19(1).

Radetsky, P. (1998). Last days of the wonder drugs. DISCOVER-NEW YORK-, 19, 76-87.

Rosa, L., Chiarelli, D. D., Tu, C., Rulli, M. C., \& D’Odorico, P. (2019). Global unsustainable virtual water flows in agricultural trade. Environmental Research Letters, 14(11), 114001.

Salami, R. I., Akindoye, O., \& Akanni, E. O. (2003). Protein and energy requirements of some cockerel starters in the tropics. Ghana journal of agricultural science, 36(1), 69-77.

Singh, N., \& Rajini, P. S. (2004). Free radical scavenging activity of an aqueous extract of potato peel. Food chemistry, 85(4), 611-616. https://doi.org/10.1016/j.foodchem.2003.07.003

Soeparno. (2005). Ilmu dan Teknologi Daging .Edisi ke 4.Gajah Mada University Press.Yogyakarta.

Soisontes, S. (2016). Sustainability in the Poultry Industry: a Case Study of Germany and Thailand. Wissenschafts-und Informationszentrum Nachhaltige Geflügelwirtschaft (WING), Universität Vechta.

Srihanam, N. (2008). Antibiotic-free feed benefits Thai native chickens. Asian Feed 168(03): 22-23.

Sulaiman, M. R., Hussain, M. K., Zakaria, Z. A., Somchit, M. N., Moin, S., Mohamad, A. S., \& Israf, D. A. (2008). Evaluation of the antinociceptive activity of Ficus deltoidea aqueous extract. Fitoterapia, 79(7-8), 557-561. https://doi.org/10.1016/j.fitote.2008.06.005

Suwarta, F. X., Suryani, C. L., \& Amien, L. (2021). Suplementasi Campuran Tepung Kunyit dan Sambiloto dalam Ransum terhadap Performan Ayam Petelur. Jurnal Peternakan Indonesia (Indonesian Journal of Animal Science), 23(2), 151-158.

Suwianggadana, I. P. A. Suciani, dan NP Sariani. 2013. Analisis finansial usaha peternakan ayam pedaging dengan pola kemitraan. Peternakan Tropika1 (2), 58.

Tian, F., Bradbury, P. J., Brown, P. J., Hung, H., Sun, Q., Flint-Garcia, S., ... \& Buckler, E. S. (2011). Genome-wide association study of leaf architecture in the maize nested association mapping population. Nature genetics, 43(2), 159-162.

Tian, L., Zhao, Y., Guo, C., \& Yang, X. (2011). A comparative study on the antioxidant activities of an acidic polysaccharide and various solvent extracts derived from herbal Houttuynia cordata. Carbohydrate Polymers, 83(2), 537-544. 
Tipakorn, N. (2002). Effects of Andrographis paniculata (Burm. F.) Nees on performance, mortality and coccidiosis in broiler chickens (Doctoral dissertation, Niedersächsische Staats-und Universitätsbibliothek Göttingen).

Ulfah, M., \& Natsir, M. H. (2018). Pemanfaatan Sambiloto, Andrographis Paniculata Nees, Sebagai Aditif Pakan Untuk Meningkatkan Performan Ayam Pedaging. Jurnal Ilmu-Ilmu Peternakan (Indonesian Journal of Animal Science), 18(1), 11-24.

Van den Bogaard, A. E., Bruinsma, N., \& Stobberingh, E. E. (2000). The effect of banning avoparcin on VRE carriage in The Netherlands. Journal of Antimicrobial Chemotherapy, 46(1), 146-148.

Warditiani, N. K., Larasanty, L. P. F., Widjaja, I. N. K., Juniari, N. P. M., Nugroho, A. E., \& Pramono, S. (2014). Identifikasi kandungan kimia ekstrak terpurifikasi herba sambiloto. Jurnal Farmasi Udayana, 3(1), 279790.

Wibowo, M. C., \& Sutrisna, E. (2020). Ekstrak Akar Sambiloto (Andrographis Paniculata Ness) Terhadap Penurunan Ldl Dan Trigliserid Pada Tikus Putih Galur Wistar.

Widyawaruyanti, A., Asrory, M., Ekasari, W., Setiawan, D., Radjaram, A., Tumewu, L., \& Hafid, A. F. (2014). In vivo antimalarial activity of Andrographis paniculata tablets. Procedia chemistry, 13, 101-104. https://doi.org/10.1016/j.proche.2014.12.012

World Health Organization. (1997). The Medical impact of the use of antimicrobials in food animals: report of a WHO meeting, Berlin, Germany, 13-17 October 1997 (No. WHO/EMC/ZOO/97.4). World Health Organization.

Yulianti, D. L., Trisunuwati, P., Sjofjan, O., \& Widodo, E. (2015). Effect of Andrographis paniculata a phytobiotic on consumption, feed conversion and Mojosari duck egg production. International Journal of Poultry Science, 14(9), 529-532.

Yunilas, E. M., \& Sinaga, O. (2005). Pengaruh pemberiaan tepung temulawak (Curcuma Xanthorrizha Roxb) dalam ransum terhadap kualitas karkas ayam broiler umur 6 minggu. Jurnal Agribisnis Peternakan, 1(2), 62-66.

Gunawijaya, G. P., Nuriyasa, I. M., \& Siti, N. W. (2021). Performance and blood lipide profile of cockerel aged 0-7 weeks that were given sambiloto leaf water extract (Andrographis paniculata ness) through drinking water. International Journal of Life Sciences, 5(3), 179-190. https://doi.org/10.53730/ijls.v5n3.2209 


\section{Biography of Authors}

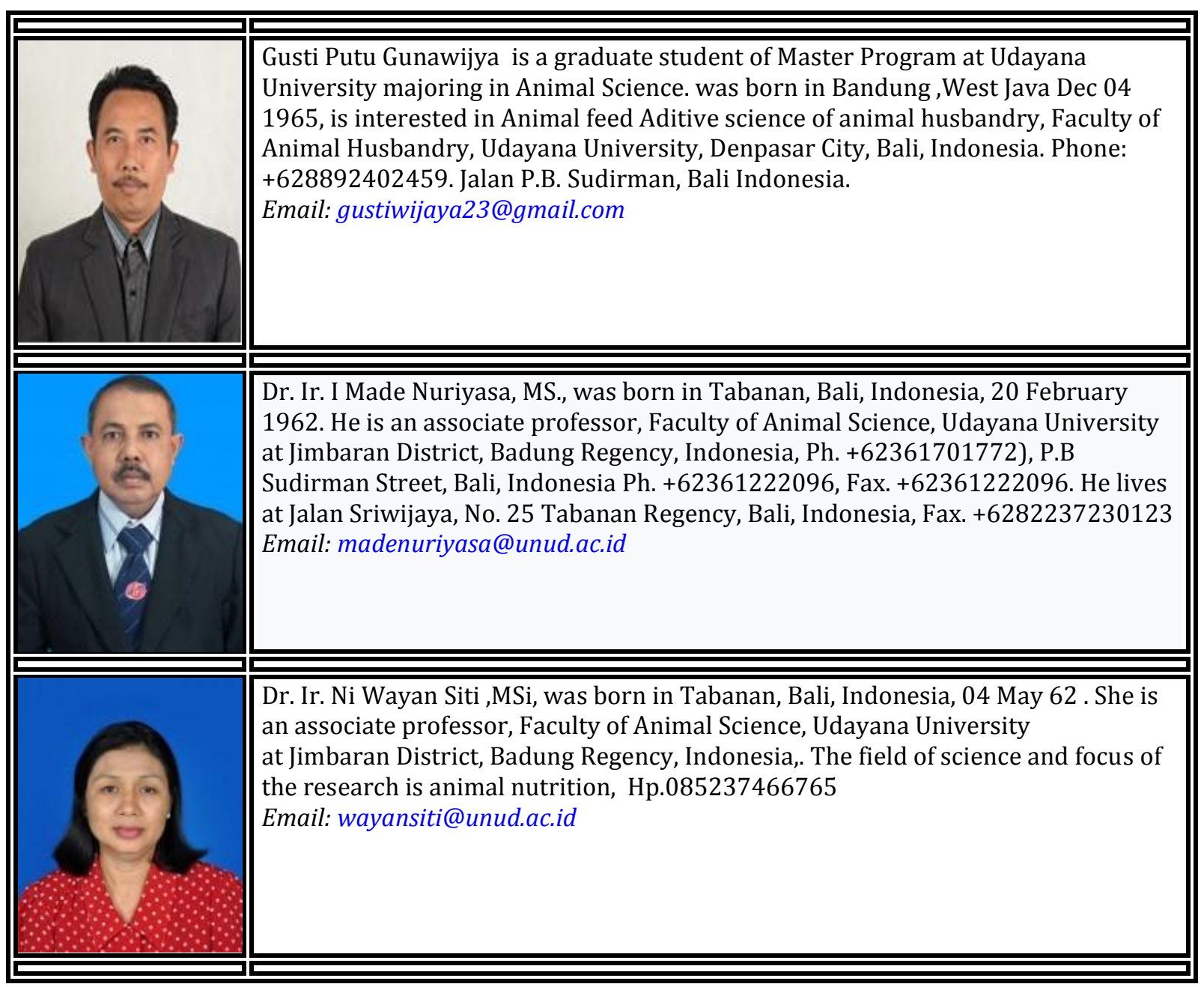

